\title{
Preparation of Naproxen-Loaded Poly(ethylene oxide- $b$-methacrylic acid) Micelle and Its pH-dependent Drug Release Behavior
}

\author{
Geun-woo Jin, Xu Ying Ji, and Joon Sig Choi ${ }^{*}$ \\ School of Chemistry \& Holecular Engineering, Seoul Kational Eniversitv, Seoul 151-742, Korea \\ ${ }^{\dagger}$ Department of Biochemistri, College of Natural Sciences. Chungnam Vational Chiversity. Daejeon $305-764$. Korea \\ ${ }^{*}$ E-mail: joonsigatanu.ac.kr \\ Received December 16. 2008, Accepted December 19. 2008
}

Key Words: Polymeric micelle. Naproxen. Poly (ethỵlene oxide). Polỵ(methacrylic acid)

To achieve effective targeted delivery and satisfactory therapentic applications. various synthetic polymers have been used for the delivery of therapeutic agents such as drugs and genes. ${ }^{1-8}$ Among synthetic polymers, amphiphilic polymers are self-assembled in aqueous solution to minimize contact between water and hydrophobic blocks, and they can contain hydrophobic dnigs in the inner hy'drophobic core. Recently, the biological signals-responsive smart micelles are reported for the selective release of drug at target organs. ${ }^{\text {? }}$ ${ }^{-12}$ Some $\mathrm{pH}$ - or glutathione-responsive micelle systems constructed with degradable polymers ${ }^{13-18}$ have been invented to target cells in the body under specific conditions. such as acidic $\mathrm{pH}$ or different concentrations of glutathione. ${ }^{19-11}$

Dnigs given by oral administration can be absorbed through a mucous membrane of small intestine and be transported to liver through the hepatic portal vein. After being metabolized in liver. drugs are circulated in the bloodstream. Some of the encapsulated drugs are released from the carriers in stomach due to its acidic environment. ${ }^{* 2}$ After passing through the stomach, the $\mathrm{pH}$ of the digestive tract increases by the secretion of the pancreatic juice containing sodium bicarbonate ${ }^{23}$ So. in this study. we designed $\mathrm{pH}$-sensitive poly meric micelle system that could encapsulate dnigs at acidic $\mathrm{pH}$ and release dnigs at basic $\mathrm{pH}$ conditions. PMMA is used for this purpose because it has low solubility at neutral and acidic $\mathrm{pHs}$, but is soluble at basic conditions due to the carboxylic acid groups. ${ }^{2+}$ We synthesized PMMA block-containing diblock copolymer. PEO- $b$-PMAA using PEO macroinitiator. The polymer formed PMMA-core micelle at neutral and acidic conditions. but the micelle will collapse due to the dissolution of PMMA in basic solution. As expected naproxen ${ }^{25}$ encapsulated in the micelle was released up to about $100 \%$ at $\mathrm{pH} 8.0$, whereas its release was restricted at $\mathrm{pH} 1.2$.

\section{Experimental Section}

Materials. Poly(etlylene glycol) monomethyl ether $\left(\mathrm{M}_{11}=\right.$ 5.000) methylene chloride (MC). tritehylamine (TEA). 2-bromoisobuty ryl bromide. fert-butyl methacrylate ( $t \mathrm{BMA}$ ). tetrahydrofuran (THF). $\mathrm{Cu}(\mathrm{I}) \mathrm{Br}$. 1.1.4.7.10.10-hexamethyltrietlyylenetetramine (HMTETA), naproxen, sodium hydroxide $(\mathrm{NaOH}) .1 .4$-dioxane and dietlyl ether were purchased from Sigma-Aldrich. Hỳdrochloride ( $\mathrm{HCl}, 37 \%$ ) and dialysis mem- brane (MWCO $=1.000)$ was purchased from Daejung Chemicals \& Metals Co.. Ltd. and Hankook Spectrum Company. respectively. Phosphate buffered saline (PBS. pH 7.4) was purchased from Biowhittaker. The $t$ BMA was passed through a short column of basic alumina and vacuum distilled prior to use in order to remove the inhibitor. THF was purified by distillation and all other chemicals were used as received.

Synthesis of PEO Macroinitiator. Poly (ethylene glycol) monomethyl ether $(25.0 \mathrm{~g} .5 .0 \mathrm{mmol})$ was dissolved in $30 \mathrm{~mL}$ of MC. TEA (1.01 g, 10.0 mmol). 2-bromoisobutyryl bromide (3.45 g. $15.0 \mathrm{mmol}$ ) was added and stirred at $4^{\circ} \mathrm{C}$ for overnight. The reaction mixture was filtered to remove triethylammonium bromide. The product in the filtrate was precipitated in 100 $\mathrm{mL}$ of diethyl ether three times and dried in vacuum.

Synthesis of PEO- $b$-PtBMA. PEO macroinitiator (1.15 g, $0.23 \mathrm{mmol}$ ). $t \mathrm{BMA}(16.37 \mathrm{~g} .115 .0 \mathrm{mmol})$, and THF $(50 \mathrm{~mL})$ were charged into a $250 \mathrm{~mL}$ flask. The reaction mixture was degassed by three freeze-punp-thaw cycles and back-filled with $\mathrm{N}_{2}$. After the reaction mixture was freezed by liquid nitrogen. $\mathrm{Cu}(\mathrm{I}) \mathrm{Br}$ ( $66.06 \mathrm{mg} .0 .46 \mathrm{numol})$ and HMTETA (106.09 mg. $0.46 \mathrm{mmol}$ ) was introduced into the reaction flask then back-filled with $\mathrm{N}_{\text {}}$. The reaction mixture inmediately became green and progressively more viscous indicating the onset of polymerization. The reaction mixture was maintained under $\mathrm{N}_{2}$ atmosphere at $60^{\circ} \mathrm{C}$. After $24 \mathrm{~h}$, the reaction solution turned blue on exposure to air. indicating aerial oxidation of the $\mathrm{Cu}(\mathrm{I})$ catalyst. The resulting copolymer solution was passed through a silica column to remove the ATRP catalyst.

Synthesis of PEO- $b$-PMAA. PEO- $b$-PtBMA was dissolved in 1.4-dioxane $(90 \mathrm{~mL}$ ) for the hydrolysis of tert-butyl ester. We added concentrated hydrochloric acid ( $37 \mathrm{wt} \% .6 \mathrm{~g} .60 .6$ nmol). and we heated the nuxture under refluxing for $12 \mathrm{~h}$. After dialysis for $24 \mathrm{~h}$ the solution was lyophilized.

${ }^{1} H$ NMR Spectroscopy. ${ }^{1} H$ NMR spectra of the polymers were obtained using a Bnuker DPX-300 NMR spectrometer (300 MHz).

Micelle Fonnation and Drug Encapsulation PEO- $b$-PMAA (100 mg) and naproxen (20 mg) were dissolved in $10 \mathrm{~mL}$ of methanol and the solution was added into $60 \mathrm{~nL}$ of distilled water. After removal of methanol by vacuum, micelle-dispersed solution was prepared. Non-encapsulated naproxen was removed by centrifuge. The empty micelle without drug was prepared by the same method as mentioned above. 
FE-SEM. Micelle solution was placed on an aluminum foil and dried to get a uniform laver of particles. then observed using FE-SEM

DLS. Micelle sizes were measured using a Zetasizer $3000 \mathrm{HAs}$ system (Malvern Instnuments. Ltd. Worcestershire. U. K.) at $25^{\circ} \mathrm{C}$. The laser used was a $10 \mathrm{~mW}$ HeNe laser and the scattered light was detected at a $90^{\circ}$ angle. Zetasizer 3000 (Advanced) Size mode v 1.61 software was used for data acquisition. The data were represented as the average value of five runs.

Dnug Release Test. In vitro release of naproxen from the micelle was determined using the dialysis membrane diffusion technique. Two $\mathrm{mL}$ of drug-loaded micelle solution was transferred into a dialysis tube (MWCO $=1,000)$ and immersed into $10 \mathrm{~mL}$ of release media ( $\mathrm{pH} 1.2$ or $\mathrm{pH} 8.0$ buffer solution) in $37^{\circ} \mathrm{C}$ and stirred at $250 \mathrm{rpm}$. Aliquots $(0.2 \mathrm{~mL})$ of the release media were withdrawn at time intervals and mixed with methanol $(0.2 \mathrm{~mL})$. The mixed solution was monitored by UV-visible spectroscopy at $330 \mathrm{~nm}$ to determine the amount of drugs released. After sampling. the release media was supplemented with $0.2 \mathrm{~mL}$ of fresh buffer solution to maintain the final volume. UV-visible absorption spectra were measured using the Shimadzu UV-1601PC spectrophotometer. The buffer solutions were prepared as follows. For the preparation of $\mathrm{pH}$ 1.2 buffer $2.0 \mathrm{~g}$ of sodium chloride and $7.0 \mathrm{~mL}$ of hydrochloride was dissolved in water to make a final volume of $1 \mathrm{~L}$. And. $\mathrm{pH}$ 8.0 buffer was prepared with PBS $(\mathrm{pH} 7.4)$ by titration with $1.0 \mathrm{M}$ of $\mathrm{NaOH}$.

\section{Results and Discussion}

Polymer Synthesis. PEO macroinitiator (PEO-Br) was synthesized by the esterification reaction of the hydroxyl end group of PEO monomethyl ether using 2-bromoisobutyryl bromide in the presence of TEA. ${ }^{26}$

${ }^{1} \mathrm{H}$ NMR ( $\left.\mathrm{D}_{2} \mathrm{O}\right): \hat{\delta} 3.65$ (m. OCH $\mathrm{CH}_{2}$ in $\mathrm{PEO}$ chain), 3.38 (s. $\mathrm{OCH}_{3}$ at $\mathrm{PEO}$ chain end). 1.90 (s, $\mathrm{CH}_{3}$ in 2-bromoisobuty ryl bromide)

The diblock copolymer was synthesized by ATRP and hydrolysis. First. $t$ BMA monomer was polymerized using PEO-Br as a macroinitiator in THF. After $24 \mathrm{~h}$ the vinyl double bonds at $\delta$ 5.5-6.0 were no longer detected by ${ }^{1} \mathrm{H}$ NMR, indicating very high conversion of the $t \mathrm{BMA}$ to $\mathrm{P} t \mathrm{BMA}(>$ $99 \%$ ).

${ }^{1} \mathrm{H}$ NMR $\left(\mathrm{CDCl}_{3}\right): \delta 3.65$ (m. $\mathrm{OCH}_{2} \mathrm{CH}_{2}$ in $\mathrm{PEO}$ chain). 3.38 (s, $\mathrm{OCH}_{3}$ at $\mathrm{PEO}$ chain end). 2.26-1.82 (br, $\mathrm{CH}_{2}$ in $\mathrm{PtBMA}$ block). 1.43 (s. $\mathrm{C}\left(\mathrm{CH}_{3}\right)_{3}$ in $t \mathrm{BMA}$ ), $1.25-0.99$ (br. $\mathrm{CH}_{3}$ groups in $\mathrm{P} t \mathrm{BMA}$ block)

The obtained PEO- $b$-PtBMA precursor was converted into PEO- $b$-PMAA by hydrolys sis in acidic solution. After $12 \mathrm{~h}$, no signals of tert-butyl groups were observed from ${ }^{\mathrm{l}} \mathrm{H}-\mathrm{NMR}$ in MeOD, indicating complete hydrolysis of tert-butyl ester groups. The degree of polymerization was estimated to be 217 based on ${ }^{l} \mathrm{H}$ NMR spectrum $\left(10.7 \mathrm{~g}\right.$, yield: $65 \%$ ). ${ }^{2 ? .28}$

${ }^{l} \mathrm{H}$ NMR (MeOD): 83.65 (m. $\mathrm{OCH}_{2} \mathrm{CH}_{2}$ in $\mathrm{PEO}$ chain). 3.38 (s. $\mathrm{OCH}_{3}$ at $\mathrm{PEO}$ chain end). 2.30-1.47 (br, $\mathrm{CH}_{2}$ groups in PMAA block), 1.47-1.01 (br. $\mathrm{CH}_{3}$ groups in PMAA block)

Micelle Fomation. PEO- $b$-PMAA block copolymer form PMAA core-micelle in an aqueous solution. Naproxen was encapsulated in hydrophobic micelle core by co-solvent evaporation method. We could calculate the percentage of naproxen encapsulated in micelle from lyophilized micelle sample. The amount of naproxen in nicelle was deternined by UV-visible spectroscopy. The encapsulation efficiency was calculated as follows $(1.15 \%)$.<smiles>CC(C)(O)CCOC(C)(C)C</smiles><smiles>CC(C)(Br)C(=O)Br</smiles><smiles>CCCC</smiles><smiles>CC(C)(C)OCCOC(=O)C(C)(C)Br</smiles><smiles>C=C(C)C(=O)OC(C)(C)C</smiles><smiles>CC(C)(Br)Br</smiles>

HCl : Dioxane<smiles>CC(C)(C)OCCOC(=O)C(C)(C)Br</smiles>

PEO macroinitiator

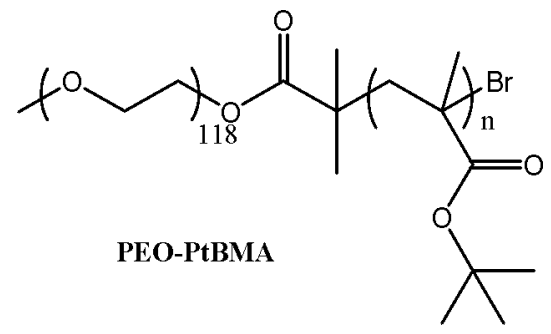<smiles>CC(C)(C)OCCOC(=O)C(C)(C)CC1(Br)CC1(Br)Br</smiles><smiles>CCCCCCCCCCCC(C)(C)C(=O)OCCOC(C)(C)C</smiles>

Scheme 1. Synthetic scheme of PEO-b-PMAA diblock copolymer. 
Encapsulation efficiency $=$

$$
\frac{\text { Weight of encapsulated drug }}{\text { Total weight of drug-loaded micelle }}
$$

The mean size of free micelles was 198.3nm. and the size of drug-loaded micelle was increased slightly to $234.9 \mathrm{~nm}$ due to dnig encapsulation (Figure 1). And we further observed the
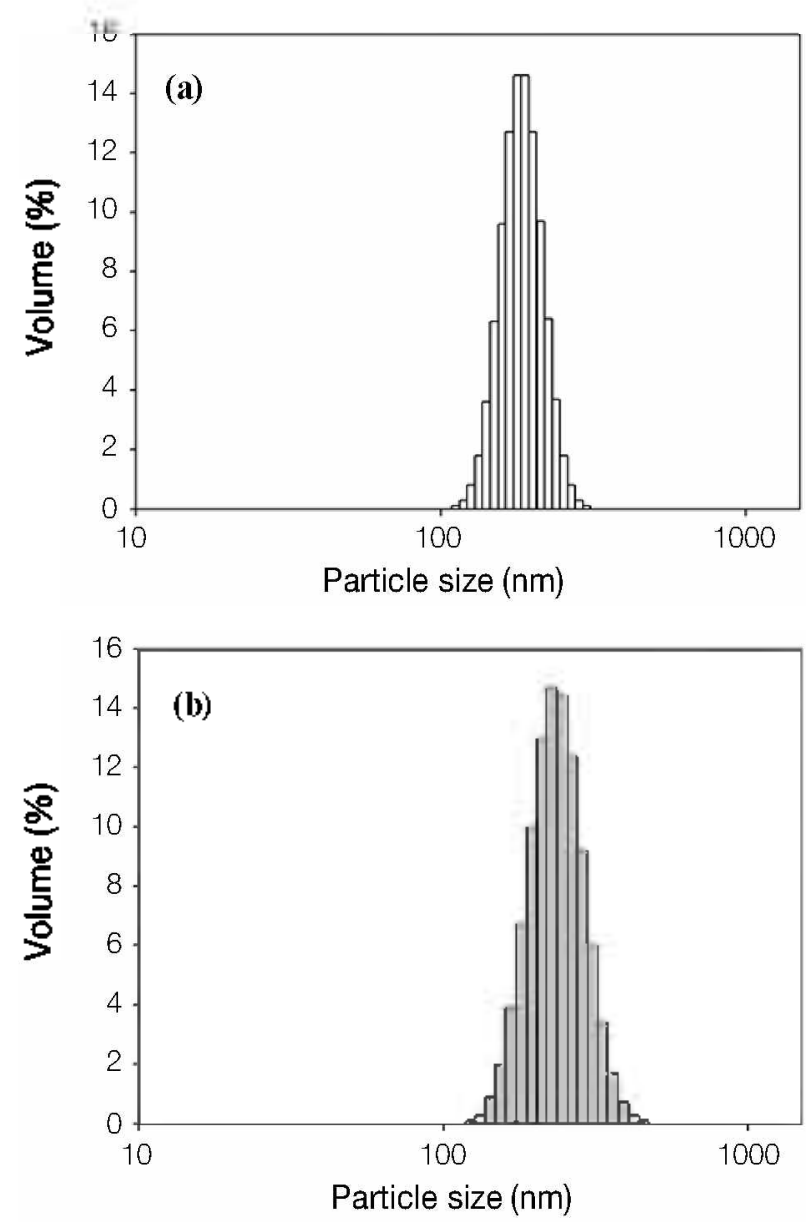

Figure 1. Size distribution of (a) PEO-b-PMAA micelle, and (b) naproxen-loaded PEO-b-PMAA micelle.

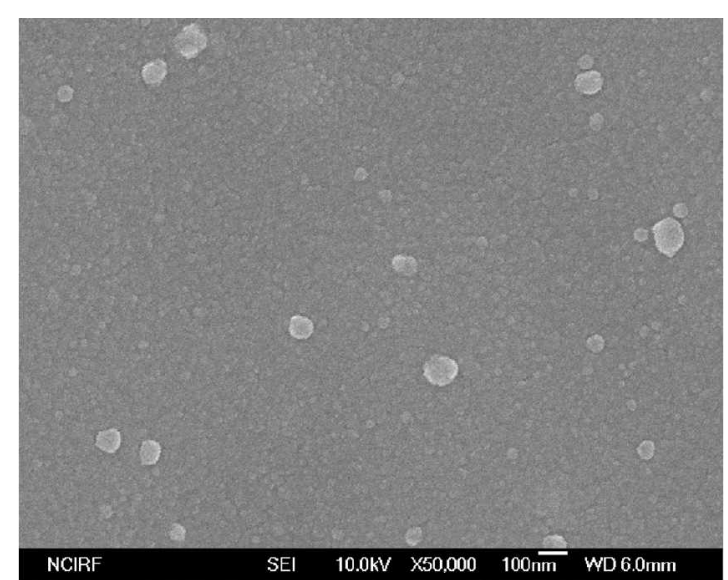

Figure 2. FE-SEM image of naproven-loaded PEO-b-PMAA micelle. appearance of the naproxen-loaded PEO- $b$-PMAA micelles by FE-SEM. The micelle displayed spherical shapes. and the size distribution was around 100-150 $\mathrm{mm}$ (Figure 2). The size observed by FE-SEM was snaller compared to the size detected by DLS. because the micelle experiences the dehydration step durning the sample preparation for FE-SEM measurements.

pH-Sensitivity of the Micelle and Dug Release. PEO- $b$ PMAA nucelle dispersed in water (neutral $\mathrm{pH}$ ) displayed a cloudy appearance due to the water-insoluble PMAA core. The photo images when aliquots $(0.2 \mathrm{~mL})$ of the opaque nucelle solution were added to $1.0 \mathrm{~mL}$ of two dufferent buffers $(\mathrm{pH} \mathrm{1.2}$, and $\mathrm{pH} 8.0$, respectively) are presented in Figure 3. The nucelle solution at $\mathrm{pH} 8.0$ became transparent compared to the other micelle at low $\mathrm{pH}$. which means that the PMAA block of the polymer is soluble in the basic solution. Because the nucelle core has changed from hydrophobic to hydrophilic state under basic conditions. hydrophobic substances encapsulated can be released at $\mathrm{pH} 8.0$ buffer. Figure 4 shows the different release patterns of naproxen at $\mathrm{pH} \mathrm{1.2}$, and $\mathrm{pH} 8.0$. Until $0.5 \mathrm{~h}$. about $30 \%$ of naproxen was released rapidly in both conditions. However. the different $\mathrm{pH}$ effect on drug release profiles was evident between the two conditions from $1 \mathrm{~h}$. The encapsulated naproxen was further released reaclung about $100 \%$ at $\mathrm{pH} 8.0$ within $2 \mathrm{~h}$, whereas more than half of the drug was maintained at $\mathrm{pH} \mathrm{1.2,} \mathrm{and} \mathrm{could} \mathrm{not} \mathrm{be} \mathrm{further}$

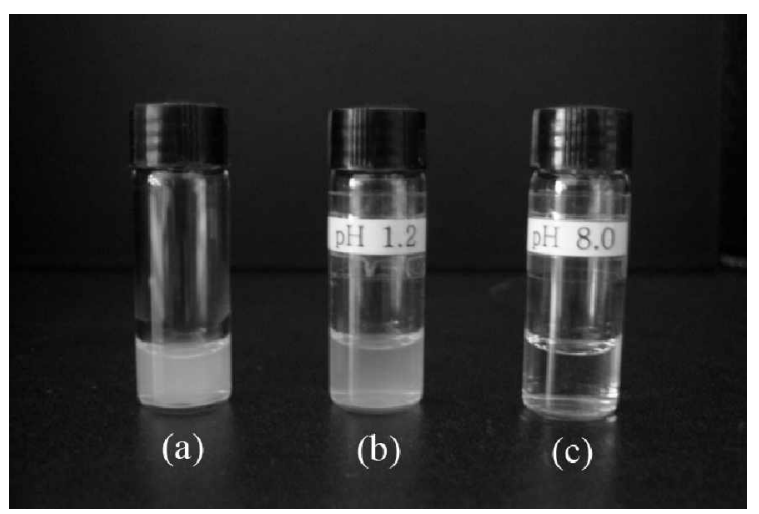

Figure 3. Photo images of $\mathrm{PEO}-b$-PMAA micelle in water (a), in $\mathrm{pH}$ 1.2 buffer (b), and in $\mathrm{pH} 80$ buffer (c).

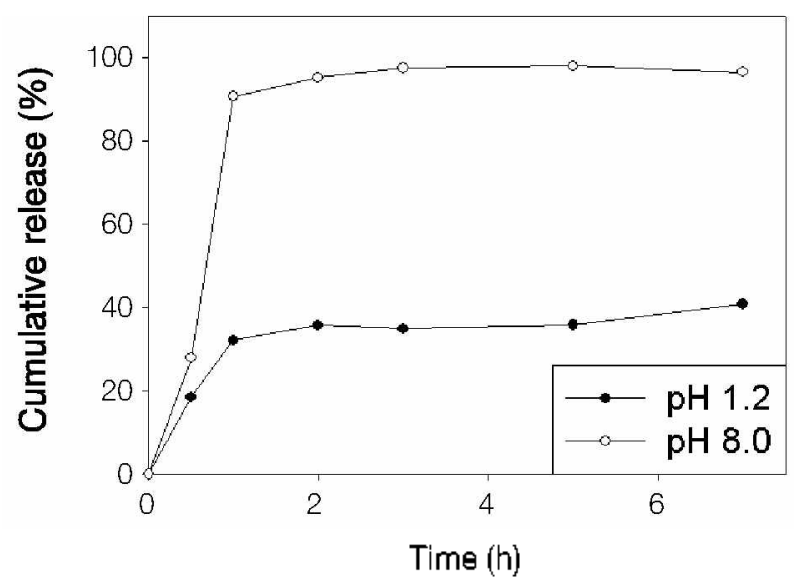

Figure 4. Cumulative release of naproxen trom PEO- $b$-PMAA micelle at $\mathrm{pH} 1.2$ and $\mathrm{pH} 8.0$. 
released to the media until $7 \mathrm{~h}$.

\section{Conclusion}

PEO-b-PMAA diblock copolymer was synthesized by ATRP. PMMA block was insoluble at neutral $\mathrm{pH}$. and the micelle was formed by co-solvent evaporation method in an aqueous solution. ${ }^{2}$ The micelle can encapsulate naproxen in the micelle core (PMMA block). The micelle contained more than half of naproxen at $\mathrm{pH} 1.2$ until $7 \mathrm{~h}$ but released up to $100 \%$ of naproxen at $\mathrm{pH} 8.0$ within $2 \mathrm{~h}$. As a result. most hydrophobic drug was maintained in PEO- $b$-PMAA at low $\mathrm{pH}$, and the drug was released rapidly at basic $\mathrm{pH}$. The results imply the potential use of PEO- $b$-PMAA micelle system for the small intestine-targeted delivery of various hỵdrophobic dnigs.

Acknowledgments. This work was supported by the Gene Therapy Project of the Ministry of Science and Technology (M10534030003-08N3403-00310).

\section{References}

1. Choi, T. S.; Lee, E. T.; Choi, Y. H.; Jeong, Y. I.; Park, I. S. Bioconingate Chem. $1999,10,62$.

2. Choi, I. S.; Joo, D. K.; Kim, C. H.; Kim, K.; Park, J. S. J. Am. Chem. Soc. 2000, 122, 474

3. Lim, Y.-B.; Kim, C.-H.: Kim, K.: Kin, S. W.; Park, J. S. J. Am. Chem. Soc. 2000, 122,6524

4. Choi, T. S. Lee, E. J.; Tang, H. S.; Park, T. S. Bioconjigate Chent. $2001,12,108$

5. Lee, T. H.: Lim, Y.-B.: Choi, J. S.; Lee, Y.: Kim, T.-I.: Kim, H. J.: Yoon, I. K.: Kinn, K.: Park, J. S. Bioconingate Chem. 2003. If, 1214

6. Choi, T. S: Nam, K: Park, T -Y.; Kim, T.-B.; Lee, I.-K ; Park, I. S. $J$. Control Release 2004, 99, 445 .

7. Kim, T.-I.: Seo, H. I; Choi, J. S.; Tang, H.-S.; Baek, J.-U.; Kim, K. Park, J. S. Biomacromolecules 2004, 5, 2487.
8. Kim. T.-I.: Baek, J.-U.: Zhe Bai, C.: Park, J. S. Biomaterials $2007,28,2061$

9. Nagasaki, Y.: Yasugi, K.: Yamamoto, Y.: Harada, A.: Kataoka, K. Biontacrontoleciles $2001,2,1067$.

10. Lee, E. S.; Na, K.; Bae, Y. H. J. Control Release 2003, $91,103$.

11. Yamamoto, Y.; Nagasaki, Y.: Kato, M.; Kataoka, K. Colloids Suf. B 1999.16.135.

12. Nah, J.-W.; Yu, L.; Han, S.-O; Ahn, C.-H.; Kim, S. W. J. Control Release 2002, 78, 273

13. Lim, Y.-B.; Choi, Y. H.: Park, J. S. J. Am Chem Soc. 1999, 121, 5633.

14. Lim, Y.-B.; Kim, S.-M; Lee, Y.; Lee, W.-K; Yang, T.-G.; Lee, M.-J. J. Am. Chem. Soc. 2001, 123, 2460.

15. Lim, Y.-B.: Kim, S.-M.; Suh, H.; Park, J S. Bioconjugate Chem. $2002,13.952$

16. Lee, Y.; Koo, H.: Tin, G.-W.; Mo, H.: Cho, M. Y.: Park, J.-Y.; Choi, J. S.; Park. J. S. Biontacrontolecules 2005, 6, 24

17. Kim, T.-I.; Seo, H. T.; Choi, J. S.; Yoon, J. K.; Baek, J.-U.; Kim, K.: Park. J. S. Bioconingate Chem. 2005. 16. 1140

18. Lee, Y.; Mo, H.: Koo, H.: Park, J.-Y.: Cho, M. Y.; Jin, G.-W:; Park, J. S. Bioconingate Chem, 2007, 18, 13.

19. Nah, J.-W.: Yu. L.; Han, S.-O; Ahn, C.-H.: Kim, S. W. J. Control Release 2002, 78, 273 .

10. Elhasi, S.; Astaneh, R.: Lavasanifar, A. Eur. J. Pham. Biopham. $2007,65,406$

21. Ko, J.; Park, K.; Kim, Y.S.; Kim, M. S.; Han, J. K.; Kim, K; Park, R.-W; Kim, I.-S; Song, H. K.; Lee, D. S.; Kwon, I. C. J. Control Release 2007, 123, 109 .

22. Xu, W.; Gao, Q.: Xu, Y.: Wu, D.; Sun, Y. Mater. Res. Bull. In Press.

23. Iwatsuki, K.; Ikeda, K.; Chiba, S. Eur. J. Phomacol. 1982, $79,53$.

24. Liu, Y.; Cáo, X.: Luo, M.; Le, Z: Xu, W. J. Colloid Interface Sci. 2009, 329, 244

25. Graf, G.; Jelen, M.; Jamnig, D.; Schabus, H.; Pipam, W.; Likar, R. Acute Pain $2008,10,131$.

26. Xu, F.-I.; Li, H.: Li, I.; Zhang, Z.; Kang, E.-T.; Neoh, K.-G. Biomaterials 2008, 29, 3023.

27. Krishuan. R.; Srinivasan, K. S. V. Eun Pohm. J. 2004, f0. 2269.

28. Sant, V. P.; Snith D; Leroux .T.-C. J. Control Release 2004, 97, 301.

29. Geng, Y: Discher, D. E. Potymter 2006, +7, 2519 